Check for updates

Cite this: Chem. Sci., 2018, 9, 8731

๑ All publication charges for this article have been paid for by the Royal Society of Chemistry

Received 27th July 2018

Accepted 17th September 2018

DOI: $10.1039 / \mathrm{c} 8 \mathrm{sc} 03346 \mathrm{c}$

rsc.li/chemical-science

\section{A general electrochemical strategy for the Sandmeyer reaction $\uparrow$}

\author{
Qianyi Liu, ${ }^{a}$ Beiqi Sun, ${ }^{a}$ Zheng Liu, ${ }^{\mathrm{b}}$ Yi Kao, ${ }^{\mathrm{b}}$ Bo-Wei Dong, ${ }^{\mathrm{b}}$ Shang-Da Jiang, (DD ${ }^{\mathrm{b}}$ \\ Feng $\mathrm{Li}^{\mathrm{c}}{ }^{\mathrm{C}}$ Guoquan Liu, (D) ${ }^{\mathrm{c}}$ Yang Yang ${ }^{\mathrm{D}}{ }^{\mathrm{d}}$ and Fanyang Mo (D) *a
}

Herein we report a general electrochemical strategy for the Sandmeyer reaction. Using electricity as the driving force, this protocol employs a simple and inexpensive halogen source, such as $\mathrm{NBS}, \mathrm{CBrCl}_{3}$, $\mathrm{CH}_{2} \mathrm{I}_{2}, \mathrm{CCl}_{4}, \mathrm{LiCl}$ and $\mathrm{NaBr}$ for the halogenation of aryl diazonium salts. In addition, we found that these electrochemical reactions could be performed using anilines as the starting material in a one-pot fashion. Furthermore, the practicality of this process was demonstrated in the multigram scale synthesis of aryl halides using highly inexpensive graphite as the electrode. A series of detailed mechanism studies have been performed, including radical clock and radical scavenger study, cyclic voltammetry analysis and in situ electron paramagnetic resonance (EPR) analysis.

\section{Introduction}

The Sandmeyer reaction represents a fundamentally important method to convert an aryl amine to an aryl halide via the intermediacy of a diazonium salt. ${ }^{1}$ Discovered in $1884,^{2,3}$ this century-old transformation is still being extensively used in modern organic synthesis in both academic and industrial settings. ${ }^{4-8}$ To date, many synthetically useful variants of the Sandmeyer reaction have been reported, including a copper metal mediated process (Gattermann reaction), ${ }^{9}$ diazotization in organic phases (Doyle diazotization), ${ }^{\mathbf{1 0}, 11}$ a $\mathrm{Cu}(\mathrm{I})$-catalyzed process $^{12}$ and acetate-facilitated metal-free halogenation. ${ }^{13}$ Despite these valuable advances, ${ }^{9-15}$ the development of a new strategy for the Sandmeyer reaction is still of great importance.

The past decade has witnessed resurging interest in organic electrochemistry that dramatically improved organic chemists' ability for green and sustainable synthesis. ${ }^{\mathbf{1 6 - 2 9}}$ Our laboratory has been engaged in the development of organic electrochemistry to overcome unmet synthetic challenges. ${ }^{30,31}$ In this context, we have recently become interested in electrocatalytic transformations of diazonium salts (Scheme 1A). An efficient electrochemical method for the Sandmeyer reaction is hampered by several factors. First, diazonium salts can engage in undesired two-electron reduction, ${ }^{32,33}$ leading to the

${ }^{a}$ Department of Energy and Resources Engineering, College of Engineering, Peking University, Beijing 100871, China. E-mail: fmo@pku.edu.cn

${ }^{b}$ Beijing National Laboratory for Molecular Sciences, College of Chemistry and Molecular Engineering, Peking University, Beijing 100871, China

${ }^{c}$ State Key Laboratory of Natural and Biomimetic Drugs, School of Pharmaceutical Sciences, Peking University, Beijing 100871, China

${ }^{d}$ Department of Chemistry, University of California, Berkeley, CA 94720, USA

$\dagger$ Electronic supplementary information (ESI) available. See DOI: $10.1039 / \mathrm{c} 8 \mathrm{sc} 03346 \mathrm{c}$ formation of an aryl anion that could be easily protonated to give a reduction product (Scheme $1 \mathrm{~B}(\mathrm{a})$ ). Second, known as the Gomberg-Bachmann reaction, ${ }^{34}$ the transient aryl radical intermediate can react with an arene or another aryl radical to give a biaryl side product (Scheme $1 \mathrm{~B}(\mathrm{~b})) .{ }^{35}$ Third, the welldocumented reaction of diazonium salts with the electrode can alter its properties and reduce the efficiency of

A. Electrochemical Sandmeyer reaction

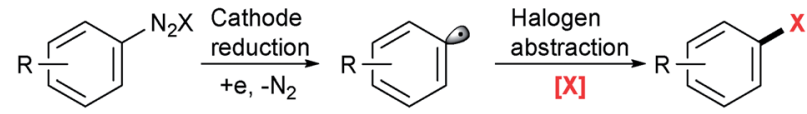

[X]: NBS, $\mathrm{CBrCl}_{3}, \mathrm{NIS}, \mathrm{CH}_{2} \mathrm{I}_{2}, \mathrm{NCS}, \mathrm{TCCA}, \mathrm{LiCl}, \mathrm{NaBr}$, etc.<smiles>O=C1CCC(=O)N1Br</smiles>

NBS<smiles>O=C1CCC(=O)N1I</smiles>

NIS<smiles>O=C1CCC(=O)N1Cl</smiles>

NCS<smiles>O=c1n(Cl)c(=O)n(Cl)c(=O)n1Cl</smiles>

TCCA

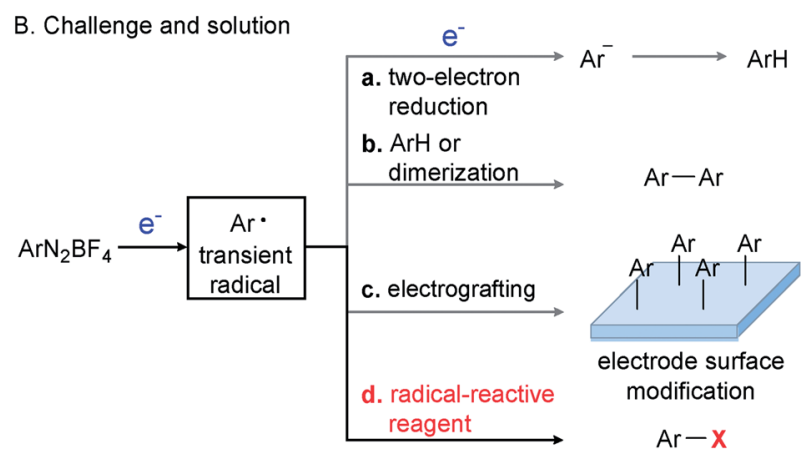

[X]

Scheme 1 Electrochemical Sandmeyer halogenation reaction. 
electrochemical processes (Scheme $1 \mathrm{~B}(\mathrm{c})) \cdot{ }^{36-38}$ We envision that the regulation of electric current to control the rate of aryl radical generation and the judicious choice of halogenation reagents to rapidly intercept the nascent aryl radical would be the key to this electrochemical Sandmeyer reaction (Scheme $1 \mathrm{~B}(\mathrm{~d}))$. In this report, we demonstrate a general electrochemical strategy for the Sandmeyer halogenation of aryl diazonium salts.

\section{Results and discussion}

The electrochemical bromination of aryldiazonium tetrafluoroborate 1a was selected as the model reaction with $\mathrm{N}$-bromosuccinimide (NBS) as the halogen source. The results are depicted in Table 1 (entries 1-7). Acetonitrile and DMF were first evaluated due to the good solubility of substrates and electrolytes in these solvents. Under these conditions, the desired product ethyl 4-bromobenzoate (2a) was formed in low yields (entries 1 and 2). The major byproduct was found to be ethyl benzoate as indicated by GC-MS analysis of the crude reaction mixture, showing that protonation or hydrogen abstraction $^{11}$ was the major undesired pathway. We then evaluated other solvents, and the use of a mixed solvent system consisting of $\mathrm{MeOH}$ and DMF (entries 3-6) provided a higher yield of 2a. Under the optimized reaction conditions using a $5: 1(\mathrm{v} / \mathrm{v})$ mixture of $\mathrm{MeOH} / \mathrm{DMF}$ as the solvent, $\mathrm{Bu}_{4} \mathrm{NClO}_{4}$ as the electrolyte and a constant current of $10 \mathrm{~mA}$ and a time of $3 \mathrm{~h}$ (3.7 $\mathrm{F} \mathrm{mol}^{-1}$ electricity), the desired bromination product (2a) was formed in $83 \%$ yield. Finally, control experiments were conducted without current (entry 7), and a significantly lower yield of 2a was observed. This demonstrated that the desired product was predominantly obtained from the electrochemical process.

The iodination of 1a was next examined (entries 8-10). Compared with $N$-iodosuccinimide (NIS) (entry 8), $\mathrm{CH}_{2} \mathrm{I}_{2}$ was found to be a better iodinating agent in this electrochemical reaction. The desired product (3a) was obtained in $87 \%$ isolated yield under the optimized conditions (entry 9). Again, this iodination was unambiguously driven by electricity as revealed by the control experiment (entry 10).

Compared with bromination and iodination, the electrochemical chlorination of diazonium salts was more challenging. Due to the higher electronegativity of chlorine, $\mathrm{NCS}^{39}$ and $\mathrm{TCCA}^{40}$ behaved more like oxidants rather than chlorine donors. Inspired by Lin's recent work on the electrocatalytic chlorination of alkenes, ${ }^{41,42}$ we used anodic oxidation to generate chlorine radicals from chloride anions. A series of alkali chlorides, cathode materials and solvents were evaluated. Ultimately, LiCl was found to be the optimal chlorine source with nickel as the cathode and acetonitrile as the solvent (entries 13-15).

With the optimal reaction conditions, we then surveyed the substrate scope (Table 2). For bromination using NBS, aryl diazonium salts with an electron-withdrawing group, including an ester (2a-2c), a nitro (2d-2g), a cyano ( $2 \mathbf{h}$ and $\mathbf{2 i})$, a halogen $(\mathbf{2 j}-\mathbf{2 l})$, a trifluoromethyl $(\mathbf{2 m})$ and a sulfonyl group (2n), furnished the corresponding brominated products in good to
Table 1 Reaction development and optimization

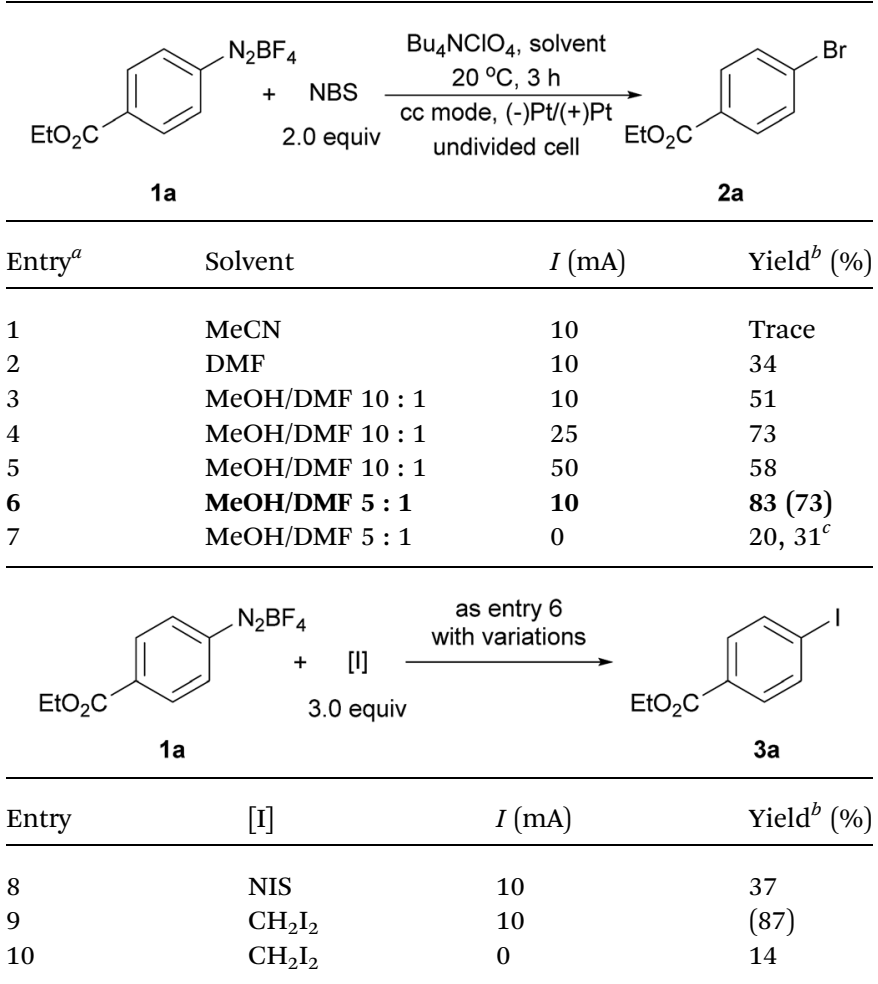

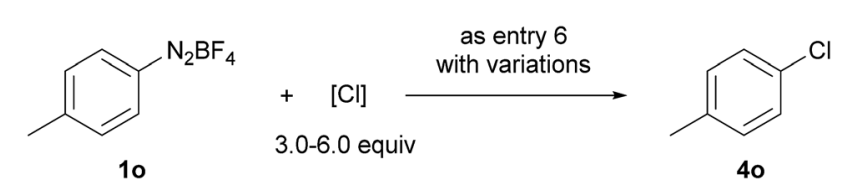

\begin{tabular}{lllll}
\hline Entry & {$[\mathrm{Cl}]$ (equiv.) } & Electrolyte & $I(\mathrm{~mA})$ & Yield $^{b}(\%)$ \\
\hline 11 & NCS (3) & $\mathrm{Bu}_{4} \mathrm{NClO}_{4}$ & 10 & 16 \\
12 & TCCA (3) & $\mathrm{Bu}_{4} \mathrm{NClO}_{4}$ & 10 & 18 \\
$13^{d}$ & $\mathrm{LiCl} \mathrm{(6)}$ & $\mathrm{LiClO}_{4}$ & 20 & 49 \\
$14^{d}$ & $\mathrm{CaCl}(5)$ & $\mathrm{LiClO}_{4}$ & 10 & Trace \\
$15^{d}$ & $\mathrm{LiCl}(6)$ & $\mathrm{LiClO}_{4}$ & 0 & 11
\end{tabular}

${ }^{a}$ Reaction conditions: 1a $(0.3 \mathrm{mmol})$, halogenation reagent [X], electrolyte ( $0.25 \mathrm{mmol}, 0.83$ equiv.), solvent $(3 \mathrm{~mL}), 20{ }^{\circ} \mathrm{C}$, and $3 \mathrm{~h} . \mathrm{cc}$, constant current. Pt mesh electrodes $\left(1 \mathrm{~cm}^{2}\right.$ each, 52 mesh) were used. ${ }^{b}$ GC-FID yields using decane as an internal standard. Isolated yields in parentheses. ${ }^{c} 15 \mathrm{~h} .{ }^{d} \mathrm{MeCN}(3 \mathrm{~mL})$ as the solvent and nickel foam $\left(1 \mathrm{~cm}^{2}\right)$ as the cathode.

excellent yields. For electron-neutral or electron-rich diazonium salts, the use of NBS led to polybromination as revealed by GCMS analysis. In these cases, $\mathrm{CBrCl}_{3}$ proved to be a better brominating agent using DMF as the solvent (2o-2t).

Moreover, under analogous electrochemical conditions, the iodination of aryl diazonium salts bearing an electronwithdrawing group, such as an ester (3a-3c), a cyano (3h and 3i), a halogen (3j-3l), a trifluoromethyl (3m), a sulfonyl (3n) and an acetyl (3u, 3v), gave good yields (63-96\%). Additionally, electron-neutral aryl diazonium salts were also suitable substrates for this procedure (3o-3q and $\mathbf{3 s}$ ). Finally, a range of diazonium salts (4a, $4 \mathbf{k}, \mathbf{4 m}, \mathbf{4 n}$ and $4 \mathbf{0})$ could be efficiently chlorinated using $\mathrm{LiCl}$ as the electrochemical chlorine reagent. 
Table 2 Scope of the diazonium salt electrochemical Sandmeyer reaction ${ }^{a}$

$\begin{gathered}2{ }^{\circ} \mathrm{C}, 10 \mathrm{~mA}, 3 \mathrm{~h} \\ (-) \mathrm{Pt} /(+) \mathrm{Pt} \\ \text { undivided cell, in air }\end{gathered}$
1<smiles>CCOC(=O)c1ccc(Br)cc1</smiles>

2a, $73 \%(83 \%)$<smiles>CCOC(=O)c1cccc(Br)c1</smiles>

2b, $42 \%(53 \%)$<smiles>CCOC(=O)c1ccccc1Br</smiles>
2c, $30 \%(52 \%)$<smiles>O=[N+]([O-])c1ccc(Br)cc1</smiles>

2d, $84 \%(86 \%)^{b, c}$<smiles>O=[N+]([O-])c1cccc(Br)c1</smiles>

$2 \mathrm{e}, 54 \%^{b}$<smiles>O=[N+]([O-])c1ccccc1Br</smiles><smiles>Cc1ccc(Br)cc1[N+](=O)[O-]</smiles>

2g, $75 \%$<smiles>N#Cc1ccc(Br)cc1</smiles><smiles>N#Cc1ccccc1Br</smiles><smiles>Clc1ccc(Br)cc1</smiles><smiles>Brc1ccc(Br)cc1</smiles><smiles>Brc1ccc(I)cc1</smiles>

2j, $52 \%$ (64\%) (NBS 3.0 equiv)

2I, $68 \%^{b}$ (NBS 3.0 equiv)<smiles>FC(F)(F)c1ccc(Br)cc1</smiles>

$2 \mathrm{~m}, 93 \%^{d}$ 2f, $61 \%^{b}$ (NBS 3.0 equiv)<smiles>COS(=O)(=O)c1ccc(Br)cc1</smiles>

2h, $84 \%$

2i, $84 \%$ (NBS 3.0 equiv)

$\mathrm{NaBr}$ (3.0 equiv)

$\mathrm{CBrCl}_{3}$ (3.0 equiv)<smiles>Cc1ccc(Br)cc1</smiles><smiles>COc1ccc(Br)cc1</smiles><smiles>Brc1ccccc1</smiles><smiles>Fc1ccc(Br)cc1</smiles>

2o, $(66 \%)^{e, f}$

2 r, $(55 \%)^{e, g}$

2s, $(75 \%)^{e}$

2t, $37 \%$, e<smiles>O=[N+]([O-])c1ccc(Br)cc1</smiles>

2d, $(49 \%)^{h}$<smiles>Cc1ccc(Br)cc1</smiles>

2o, $(66 \%)^{h}$<smiles>COc1ccc(Br)cc1</smiles>

2 r, $(37 \%)^{n}$<smiles>Brc1ccccc1</smiles>

2s, $(62 \%)^{h}$

$\mathrm{CH}_{2} \mathrm{I}_{2}$ (3.0 equiv)<smiles>CCOC(=O)c1cccc(I)c1</smiles>

3a, $87 \%$

3b, $87 \%$<smiles>Ic1ccc(I)cc1</smiles>

3I, $56 \%(77 \%)$<smiles>FC(F)(F)c1ccc(I)cc1</smiles>

$3 \mathrm{~m}, 96 \%^{d}$<smiles>CCOC(=O)c1ccccc1I</smiles>

3c, $74 \%$<smiles>O=[N+]([O-])c1ccc(I)cc1</smiles>

3d, $(45 \%)^{9}$<smiles>N#Cc1ccc(I)cc1</smiles>

3h, $93 \%$<smiles>N#Cc1ccccc1I</smiles>

3i, $76 \%$<smiles>Clc1ccc(I)cc1</smiles>

3j, $60 \%(81 \%)$<smiles>Brc1ccc(I)cc1</smiles>

3k (2I), 61\% (89\%)<smiles>Ic1ccccc1</smiles>

3s, $(78 \%)$<smiles>CS(=O)(=O)c1ccc(I)cc1</smiles>

3n, $63 \%$<smiles>Cc1ccc(I)cc1</smiles>

3o, $(71 \%)$

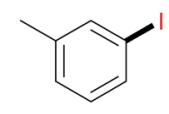

3p, $(47 \%)$

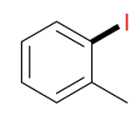

3q. $(53 \%)$<smiles>COc1ccc(C)cc1</smiles><smiles>Fc1ccc(I)cc1</smiles>

$3 \mathbf{r},(37 \%)$ (6)

LiCl (6.0 equiv)<smiles>CCOC(=O)c1ccc(Cl)cc1</smiles>

4a, $(36 \%)^{h, i}$<smiles>Clc1ccc(Br)cc1</smiles>

4k (2j), $(37 \%)^{h, i}$<smiles>CC(=O)c1ccc(I)cc1</smiles>

3u, $87 \%$<smiles>N#Cc1ccccc1I</smiles><smiles>C=C(Cl)/C=C\C</smiles><smiles>CN1C(=O)c2ccc(I)cc2C1=O</smiles>

$3 w, 68 \%$<smiles>Ic1cccc2cccnc12</smiles>

$3 v, 70 \%$<smiles>FC(F)(F)c1ccc(Cl)cc1</smiles>

$4 \mathrm{~m}, 31 \%^{d, h, i}$<smiles>COS(=O)(=O)c1ccc(Cl)cc1</smiles>

4n, $64 \%{ }^{h, i}$<smiles>Cc1ccc(Cl)cc1</smiles>

4o, $(49 \%)^{h, i}$

\footnotetext{
${ }^{a}$ Reaction conditions: 1 ( $\left.0.3 \mathrm{mmol}\right), \mathrm{Bu}_{4} \mathrm{NClO}_{4}\left(0.25 \mathrm{mmol}, 0.83\right.$ equiv.), $\mathrm{CH}_{3} \mathrm{OH}(2.5 \mathrm{~mL})$ and $\mathrm{DMF}(0.5 \mathrm{~mL}), 20^{\circ} \mathrm{C}, 3 \mathrm{~h}$, and constant current $10 \mathrm{~mA}$. Pt mesh electrodes $(1 \mathrm{~cm} \times 1 \mathrm{~cm})$ were used. Isolated yields were given. GC-FID yields in parentheses were given due to either product volatility or difficulty in isolation with by-products (e.g. ArH). ${ }^{b} \mathrm{CH}_{3} \mathrm{OH} / \mathrm{DMF} 20: 1$ (total $3.0 \mathrm{~mL}$ ). ${ }^{c} 1 \mathrm{~h} .{ }^{d}{ }^{19} \mathrm{~F}$ NMR yields determined using 4 -(trifluoromethoxy) anisole as an internal standard. ${ }^{e} \mathrm{DMF}(3 \mathrm{~mL}) .{ }^{f} 4.5 \mathrm{~h}^{g}{ }^{g} 2 \mathrm{~h} .{ }^{h} \mathrm{MeCN}(3 \mathrm{~mL})$, $\mathrm{LiClO}_{4}(0.5 \mathrm{mmol})$ as the electrolyte. ${ }^{i} 20 \mathrm{~mA}, \mathrm{Ni}$ foam cathode.
}

For instance, sulfone substituted product $4 \mathbf{n}$ was obtained in $64 \%$ isolated yield.

Anilines are broadly available starting materials for organic synthesis. Thus, it is highly desirable to perform an in situ diazotization/electrochemical reaction to directly employ anilines as the precursors for halogenation. As shown in Table 3, a diverse array of aryl amines were successfully transformed to the corresponding halogenated products in good to 
Table 3 One pot diazotization/electrochemical reaction ${ }^{a}$

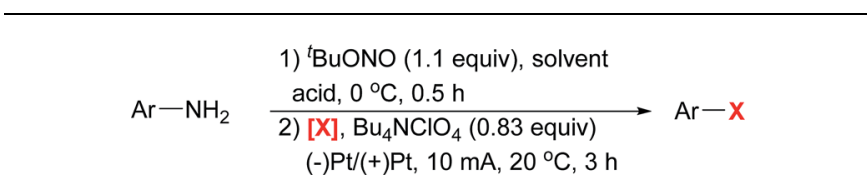

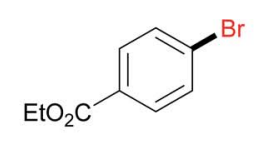

2a, $(60 \%)$ NBS (2.0 equiv)<smiles>COc1ccc(Br)cc1</smiles>

$2 \mathbf{r},(61 \%)$ $\mathrm{CBrCl}_{3}$ (3.0 equiv)<smiles>N#Cc1ccc(Br)cc1</smiles>

2h, $(83 \%)$ NBS ( 2.0 equiv)<smiles>CC(C)(C)c1ccc(Br)cc1</smiles>

2y, $(53 \%)$

$\mathrm{CBrCl}_{3}$ (3.0 equiv)

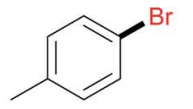

2o, $(57 \%)$ $\mathrm{CBrCl}_{3}$ (3.0 equiv)<smiles>Brc1ccc(-c2ccccc2)cc1</smiles>

$2 \mathbf{z},(42 \%)$ $\mathrm{CBrCl}_{3}$ (3.0 equiv)<smiles>CCOC(=O)c1ccc(I)cc1</smiles>

3a, $(76 \%)$ $\mathrm{CH}_{2} \mathrm{I}_{2}$ (3.0 equiv) 3aa, $72 \%$ $\mathrm{CH}_{2} \mathrm{I}_{2}$ (3.0 equiv)<smiles>CCNc1ccc(I)cc1</smiles>

3ab, $78 \%$ $\mathrm{CH}_{2} \mathrm{I}_{2}$ (3.0 equiv)<smiles>CCOC(=O)CNC(=O)c1ccc(I)cc1</smiles>

3ac, $71 \%$ $\mathrm{CH}_{2} \mathrm{I}_{2}$ (3.0 equiv) 3ad, $53 \%$ $\mathrm{CH}_{2} \mathrm{I}_{2}$ (3.0 equiv) 3ae, $45 \%$ $\mathrm{CH}_{2} \mathrm{I}_{2}$ (3.0 equiv)<smiles>Cc1c(C)c2c(c(C)c1OC(=O)c1ccc(I)cc1)CC[C@@](C)(CCC[C@H](C)CCC[C@H](C)CCCC(C)C)O2</smiles>

3af, $59 \%$ $\mathrm{CH}_{2} \mathrm{I}_{2}$ (3.0 equiv)

${ }^{a}$ Reaction conditions: aryl amine $(0.3 \mathrm{mmol}),{ }^{t} \mathrm{BuONO}(0.33 \mathrm{mmol}, 1.1$

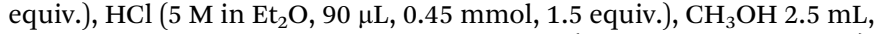
DMF $0.5 \mathrm{~mL}, 0{ }^{\circ} \mathrm{C}$, and $0.5 \mathrm{~h}$; then $\mathrm{Bu}_{4} \mathrm{NClO}_{4}(0.25 \mathrm{mmol}, 0.83$ equiv.), $[\mathrm{X}], 20^{\circ} \mathrm{C}, 3 \mathrm{~h}$, and constant current $10 \mathrm{~mA}$. Pt mesh electrodes $(1 \mathrm{~cm}$ $\times 1 \mathrm{~cm}$ ) were used. Isolated yields were given. GC-FID yields were shown in parentheses. For details, see the ESI.

excellent yields (42-83\%). This one-pot protocol tolerated a number of functional groups, such as a boronic ester (3aa), an amide (3ab-3ad) and an indole (3ae). In general, aryl amines with an electron-withdrawing group gave a relatively higher yield. For instance, bromination of 4-cyanoaniline under the one-pot protocol gave $83 \%$ GC yield (2h); iodination of $N$-(4-aminophenyl)acetamide gave $78 \%$ isolated yield (3ab). Moreover, it is noteworthy that the aniline derived from vitamin E was also iodinated in 59\% isolated yield (3af).
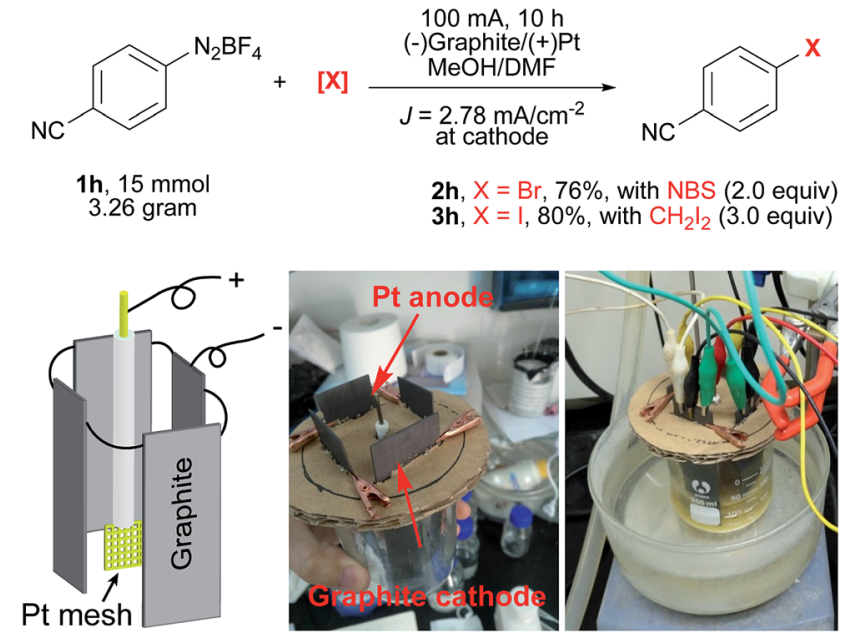

Scheme 2 Gram-scale electrochemical Sandmeyer reactions. A Pt mesh electrode $(1 \mathrm{~cm} \times 1 \mathrm{~cm}, 52$ mesh) as the anode, and 4 graphite plates $(4 \times 3 \mathrm{~cm} \times 3 \mathrm{~cm}$ immersed in the solution) as the cathodes.

To further demonstrate the utility of this electrochemical protocol, gram-scale experiments were next carried out. Since the electrochemical reduction of diazonium salts takes place at the cathode, we applied inexpensive graphite plate electrodes with a large size to lower the current density $\left(J=2.78 \mathrm{~mA} \mathrm{~cm}^{-2}\right)$. By using the setup shown in Scheme 2, $\mathbf{2 h}$ was prepared from $\mathbf{1 h}$ on a three-gram scale (15 mmol) in $76 \%$ yield. Similarly, $3 \mathrm{~h}$ was prepared on a three-gram scale in $80 \%$ yield.

To probe this electrically generated aryl radical species, we carried out a range of mechanistic experiments. First, a radical clock experiment was performed by using diazonium salt $\mathbf{5}$ derived from 2-(allyloxy)aniline as the substrate (Scheme 3A). We obtained only the cyclized product 6 in $37 \%$ yield as determined by ${ }^{1} \mathrm{H}$ NMR spectroscopy, and the acyclic product was not detected by GC-MS and ${ }^{1} \mathrm{H}$ NMR analysis. Next, an

A. Electrochemical clock reaction

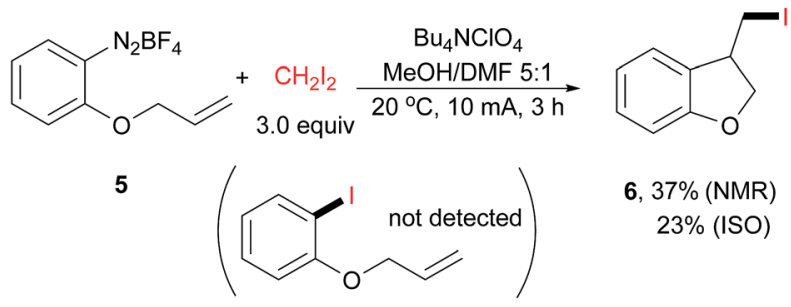

B. Reaction with TEMPO

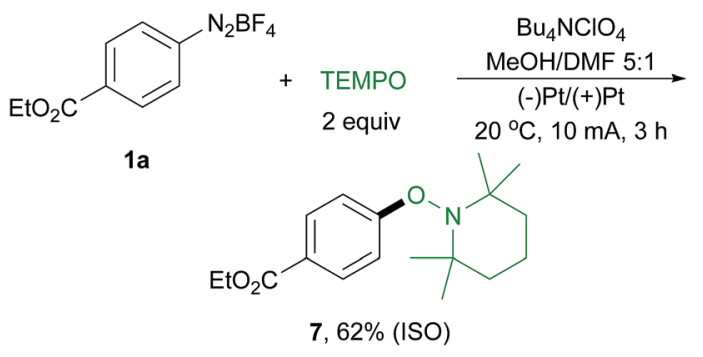

Scheme 3 Control experiments. 


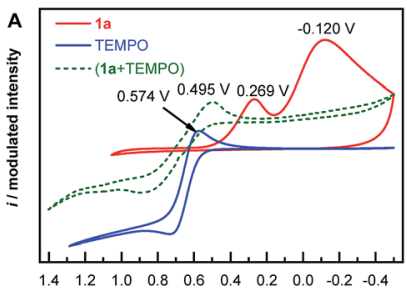

E/V vs SCE

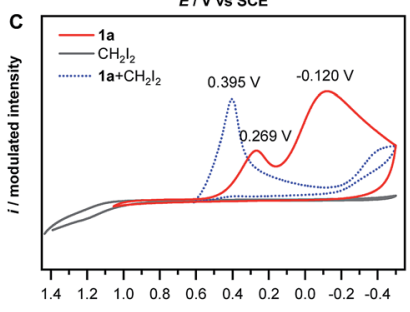

EIV VS SCE

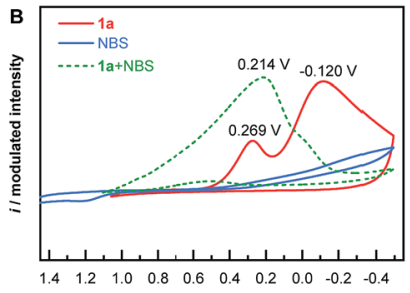

EIV vs SCE

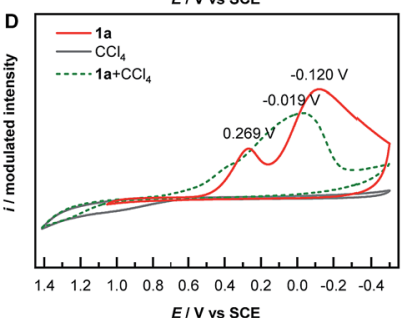

Fig. 1 Cyclic voltammetry curves.

electrochemical reaction of $\mathbf{1 a}$ with 2,2,6,6-tetramethyl-1piperidinyloxy (TEMPO) was conducted, affording arylated product 7 in $62 \%$ isolated yield (Scheme 3B). This is well in accord with Studer's report. ${ }^{43}$ In their paper, they have demonstrated that TEMPONa is capable of reducing diazonium salt to its aryl radical, thus facilitating the following transformation.

The mechanism of electrochemical reduction of diazonium salt has been studied by means of polarography. ${ }^{44}$ Here we further apply this technique in our reaction system. Thus, cyclic voltammetry $(\mathrm{CV})$ measurements of $\mathbf{1 a}$ with a series of radicalreactive reagents were taken. The CV curve of 1a gave two waves, corresponded to the reduction of aryl diazonium to aryl radicals and further to aryl anions, respectively. This is in good agreement with a literature report. ${ }^{45}$ However the CV curves of 1a with reagents (TEMPO, NBS, $\mathrm{CH}_{2} \mathrm{I}_{2}$ and $\mathrm{CCl}_{4}$ in these cases, respectively) give only one reduction peak, indicating that the nascent aryl radical reacts with these reagents, and thus likely has no chance to be further reduced on the cathode (Fig. 1). These experimental results are consistent with the hypothesis shown in Scheme $1 \mathrm{~B}(\mathrm{~d})$.

Electron paramagnetic resonance (EPR) is a spectroscopic technique capable of detecting and identifying paramagnetic species, such as organic radicals, thus providing essential information on the nature of reactive intermediates in single electron transfer reactions. EPR spectroscopy has been
A
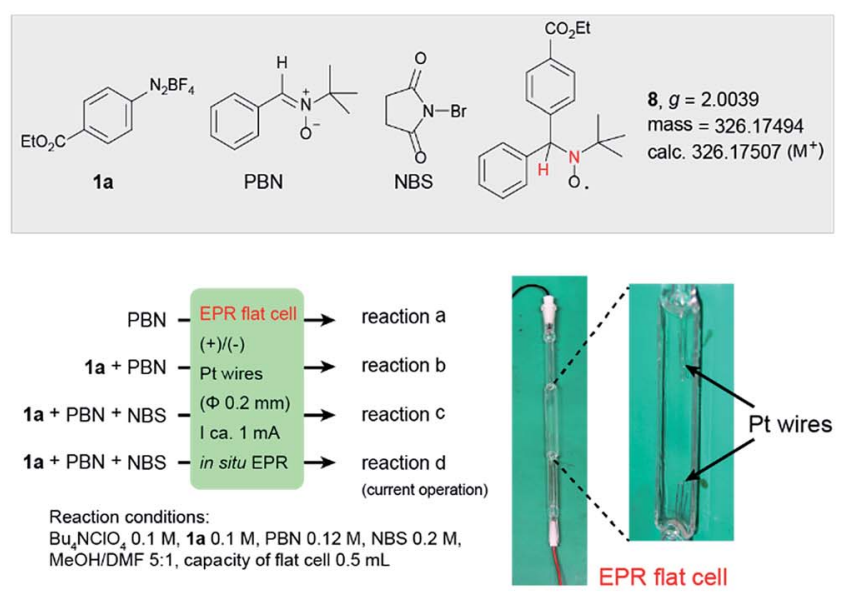

C
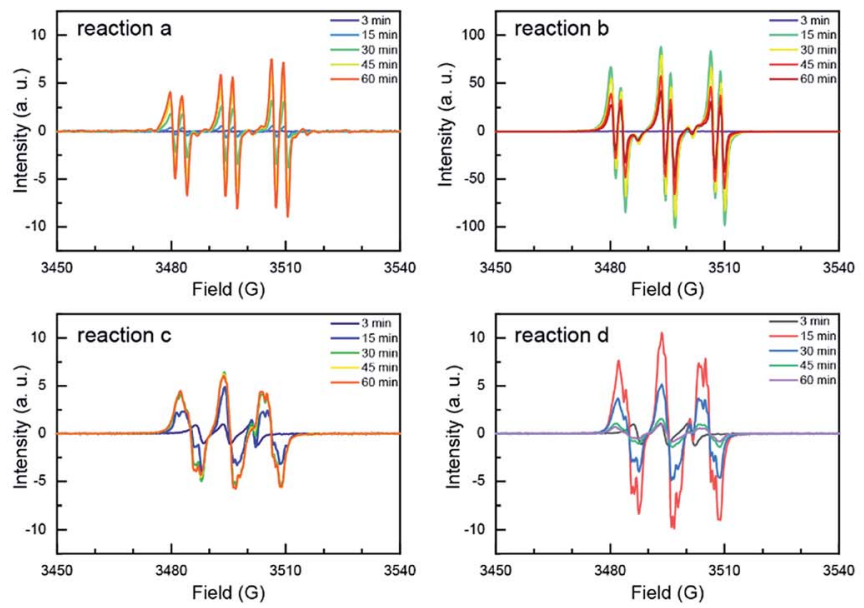

B
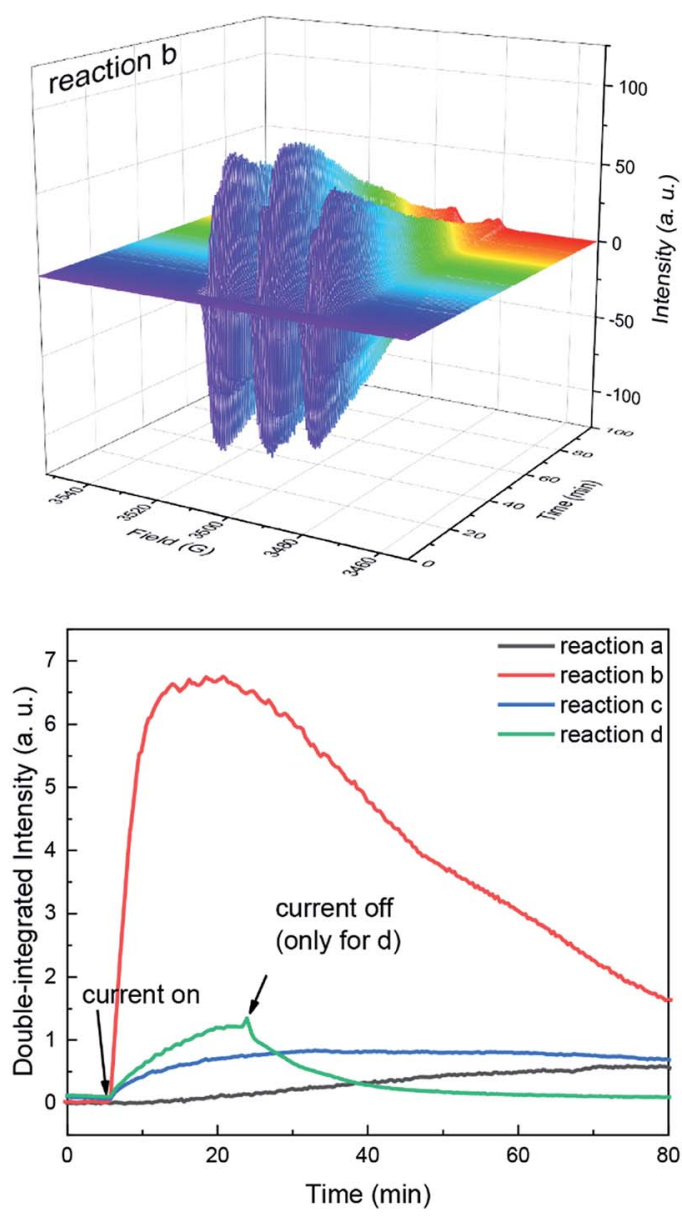

Fig. 2 (A) Four in situ EPR electrochemical reactions. Photograph of an EPR flat cell with a home-made electrolysis setup is shown. (B) Time dependent EPR profile of reaction b. For the EPR profile of reactions a, $c$ and d, see Fig. S5 in the ESI. $\uparrow$ (C) EPR signal at different times of reactions $a-d$. (D) Time evolution of the double-integrated intensity of the signals of in situ EPR electrochemical reactions a-d. a.u., arbitrary unit. 
extensively utilized to study electrochemically generated organic radicals. ${ }^{46}$ Here, we applied EPR spectroelectrochemistry to study the current electrochemical Sandmeyer reaction. In our setup, we combined a common Bruker Elexsys E580 spectrometer with a super-high sensitivity probe head $(\omega$ $=9.80 \mathrm{GHz})$ and a standard flat cell $(0.3 \mathrm{~mm}$ in depth) with ultrathin Pt wires $(\Phi 0.2 \mathrm{~mm}$ ) for this in situ study (Fig. 2A). Using this setup, electrolysis experiments and in situ EPR measurements were first performed on samples containing diazonium salt $1 \mathrm{a}$ and NBS in $\mathrm{MeOH} / \mathrm{DMF}$ with $n-\mathrm{Bu}_{4} \mathrm{NClO}_{4}$ as the electrolyte. EPR signals were not observed, presumably due to the high reactivity and low concentration of these radical intermediates. Consequently, $\mathrm{N}$-benzylidene-tert-butylamine $\mathrm{N}$ oxide (PBN) was introduced into the experiments as a spintrap. ${ }^{47}$ Spin-traps react with short-lived radicals and convert them to more stable, EPR detectable radical species. The choice of PBN is based on Bard's report, ${ }^{48}$ where they found that PBN is electroinactive between 1.5 and $-2.4 \mathrm{~V}$ (vs. SCE). Thus, four electrochemical reactions a-d were followed by in situ EPR spectroscopy using PBN as the spin-trap (Fig. 2A). The EPR spectrum was acquired in an interval of $30 \mathrm{~s}$ over the course of $100 \mathrm{~min}$. These EPR signals were then compiled as a time dependent 2D profile (for reaction b, see Fig. 2B; for reactions a, c and d, see Fig. S5 $\dagger$ ). Fig. 2C shows the EPR signals of these reactions at different reaction times, and Fig. 2D shows time dependent double-integrated intensity of these in situ EPR signals.

In these reactions, no major EPR signal is observed until electricity is on. The isotropic $g$ factor and hyperfine coupling constants of these radical EPR signals were simulated using the least-squares fitting method with EasySpin's function garlic (for

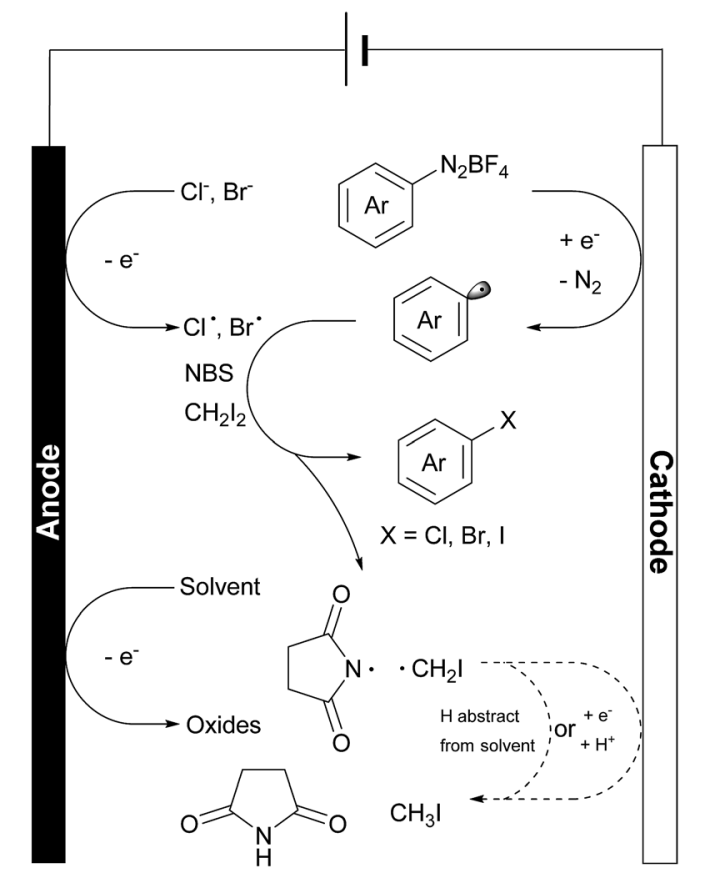

Scheme 4 Proposed reaction events on both electrodes and in solvent bulk. details, see the ESI $\dagger$ ). As expected, radicals in reactions a, b and $c$ are different and in $d$ they resemble those in c (Fig. 2C). The contrasting growth rates of intensity shown in Fig. 2D provided valuable mechanistic information. By comparing reactions $\mathrm{a}$ and $\mathrm{b}$, a rapid growth observed in reaction $\mathrm{b}$ indicated that diazonium salt 1a was rapidly reduced to an aryl radical upon electrolysis. The resulting aryl radical was trapped by PBN to afford an EPR active species. Based on a six-line EPR spectrum $\left(g=2.0039, a_{\mathrm{N}}=13.02 \mathrm{G} \text {, and } a_{\mathrm{H}}=2.37 \mathrm{G}\right)^{47,48}$ and HRMS data, this radical could be likely attributed to compound 8 . In reactions $\mathrm{c}$ and $\mathrm{d}$, the intensity grew slowly as compared with reaction $b$, indicating that the addition of NBS changes the reaction pathway of electrically generated radicals. In reaction $\mathrm{d}$, the intensity rapidly decayed when the current was turned off, also demonstrating an electricity driven radical generation process. These in situ EPR electrochemical experiments and previous cyclic voltammetry studies demonstrated that diazonium salts can readily undergo single electron reduction processes on the cathode, and the resulting aryl radical is a highly reactive species that can be trapped by many radical trapping reagents, such as NBS, $\mathrm{CH}_{2} \mathrm{I}_{2}, \mathrm{PBN}$ and TEMPO. Meanwhile, the solvents (e.g. $\mathrm{MeOH})$ can be oxidized on the anode $^{49}$ to balance the overall transformation (Scheme 4).

\section{Conclusion}

In summary, we have developed a general electrochemical protocol for the Sandmeyer halogenation process. A diverse range of functional groups were compatible with this electrochemical reaction. Anilines can be directly employed as the starting material, further expanding the utility of this method. Moreover, this method is amenable to the large-scale synthesis of aryl halides, and very inexpensive graphite can be employed instead of platinum as the cathode material for this large-scale preparation. Importantly, detailed mechanism studies, including the application of rarely used in situ EPR measurements, support a single electron reduction mechanism for the halogenation of diazonium salts upon electrolysis. This electrochemical process could be a complementary method for the existing Sandmeyer halogenation reactions, and might inspire other Sandmeyer type transformations (e.g. noble metal free trifluoromethylation $\left.{ }^{50-52}\right)$ in the near future.

\section{Conflicts of interest}

There are no conflicts to declare.

\section{Acknowledgements}

We thank Prof. Chao $\mathrm{Li}$ at National Institute of Biological Sciences (Beijing) for insightful discussion. The project is supported by the Natural Science Foundation of China (Grants 21502003 and 21772003). We also thank the "1000-Youth Talents Plan" and Peking University for start-up funds. Y. Y. thanks the Miller Institute for Basic Research in Science at UC Berkeley for a post-doctoral fellowship. 


\section{Notes and references}

1 L. Kurti and B. Czakó, Strategic applications of named reactions in organic synthesis, Elsevier, 2005.

2 T. Sandmeyer, Ber. Dtsch. Chem. Ges., 1884, 17, 1633-1635.

3 T. Sandmeyer, Ber. Dtsch. Chem. Ges., 1884, 17, 2650-2653.

4 H. H. Hodgson, Chem. Rev., 1947, 40, 251-277.

5 C. Galli, Chem. Rev., 1988, 88, 765-792.

6 E. B. Merkushev, Synthesis, 1988, 1988, 923-937.

7 F. Mo, G. Dong, Y. Zhang and J. Wang, Org. Biomol. Chem., 2013, 11, 1582-1593.

8 F. Mo, D. Qiu, Y. Zhang and J. Wang, Acc. Chem. Res., 2018, 51, 496-506.

9 L. Gattermann and A. Cantzler, Ber. Dtsch. Chem. Ges., 1892, 25, 1086-1091.

10 M. P. Doyle, J. F. Dellaria, B. Siegfried and S. W. Bishop, J. Org. Chem., 1977, 42, 3494-3498.

11 M. P. Doyle, B. Siegfried and J. F. Dellaria Jr, J. Org. Chem., 1977, 42, 2426-2431.

12 I. P. Beletskaya, A. S. Sigeev, A. S. Peregudov and P. V. Petrovskii, Synthesis, 2007, 2007, 2534-2538.

13 D. A. Leas, Y. Dong, J. L. Vennerstrom and D. E. Stack, Org. Lett., 2017, 19, 2518-2521.

14 J. G. Lee and H. T. Cha, Tetrahedron Lett., 1992, 33, 31673168.

15 H. Yang, L. Fu, L. Wei, J. Liang and B. P. Binks, J. Am. Chem. Soc., 2015, 137, 1362-1371.

16 K. D. Moeller, Tetrahedron, 2000, 56, 9527-9554.

17 J. B. Sperry and D. L. Wright, Chem. Soc. Rev., 2006, 35, 605621.

18 A. Jutand, Chem. Rev., 2008, 108, 2300-2347.

19 J.-i. Yoshida, K. Kataoka, R. Horcajada and A. Nagaki, Chem. Rev., 2008, 108, 2265-2299.

20 R. Francke and R. D. Little, Chem. Soc. Rev., 2014, 43, $2492-$ 2521.

21 E. J. Horn, B. R. Rosen and P. S. Baran, ACS Cent. Sci., 2016, 2, 302-308.

22 R. Feng, J. A. Smith and K. D. Moeller, Acc. Chem. Res., 2017, 50, 2346-2352.

23 Y. Jiang, K. Xu and C. Zeng, Chem. Rev., 2018, 118, 44854540.

24 M. Yan, Y. Kawamata and P. S. Baran, Chem. Rev., 2017, 117, 13230-13319.

25 A. Wiebe, T. Gieshoff, S. Möhle, E. Rodrigo, M. Zirbes and S. R. Waldvogel, Angew. Chem., Int. Ed., 2018, 57, 5594-5619.

26 S. Möhle, M. Zirbes, E. Rodrigo, T. Gieshoff, A. Wiebe and

S. R. Waldvogel, Angew. Chem., Int. Ed., 2018, 57, 6018-6041. 27 G. S. Sauer and S. Lin, ACS Catal., 2018, 8, 5175-5187.

28 S. Tang, Y. Liu and A. Lei, Chem, 2018, 4, 27-45.
29 S. R. Waldvogel, S. Lips, M. Selt, B. Riehl and C. J. Kampf, Chem. Rev., 2018, 118, 6706-6765.

30 L. Zhang, Z. Zhang, J. Hong, J. Yu, J. Zhang and F. Mo, J. Org. Chem., 2018, 83, 3200-3207.

31 L. Zhang, Z. Zhang, J. Zhang, K. Li and F. Mo, Green Chem., 2018, 20, 3916-3920.

32 E. R. Atkinson, C. E. Garland and A. F. Butler, J. Am. Chem. Soc., 1953, 75, 983-984.

33 J. K. Kochi, J. Am. Chem. Soc., 1955, 77, 3208-3211.

34 M. Gomberg and W. E. Bachmann, J. Am. Chem. Soc., 1924, 46, 2339-2343.

35 E. R. Atkinson, C. R. Morgan, H. H. Warren and T. J. Manning, J. Am. Chem. Soc., 1945, 67, 1513-1515.

36 D. Belanger and J. Pinson, Chem. Soc. Rev., 2011, 40, 39954048.

37 G. L. C. Paulus, Q. H. Wang and M. S. Strano, Acc. Chem. Res., 2013, 46, 160-170.

38 A. Berisha, M. M. Chehimi, J. Pinson and F. Podvorica, Electroanalytical Chemistry, A Series of Advances, 2015, vol. 26, pp. 115-224.

39 S. C. Virgil, T. V. Hughes, D. Qiu and J. Wang, in Encyclopedia of Reagents for Organic Synthesis, John Wiley \& Sons, Ltd, 2001, DOI: 10.1002/047084289X.rc145.pub3.

40 G. A. Hiegel, G. Pozzi and AnuMahadevan, in Encyclopedia of Reagents for Organic Synthesis, John Wiley \& Sons, Ltd, 2001, DOI: 10.1002/047084289X.rt209.pub3.

41 N. Fu, G. S. Sauer and S. Lin, J. Am. Chem. Soc., 2017, 139, 15548-15553.

42 K.-Y. Ye, G. Pombar, N. Fu, G. S. Sauer, I. Keresztes and S. Lin, J. Am. Chem. Soc., 2018, 140, 2438-2441.

43 M. Hartmann, Y. Li and A. Studer, J. Am. Chem. Soc., 2012, 134, 16516-16519.

44 R. M. Elofson and F. F. Gadallah, J. Org. Chem., 1969, 34, 854-857.

45 E. R. Atkinson, H. H. Warren, P. I. Abell and R. E. Wing, J. Am. Chem. Soc., 1950, 72, 915-918.

46 P. Rapta, E. Dmitrieva, A. A. Popov and L. Dunsch, in Organic Electrochemistry: Revised and Expanded, ed. O. Hammerich and B. Speiser, CRC Press, 5 edn, 2016, ch. 3, pp. 169-190.

47 G. R. Buettner, Free Radical Biol. Med., 1987, 3, 259-303.

48 A. J. Bard, J. C. Gilbert and R. D. Goodin, J. Am. Chem. Soc., 1974, 96, 620-621.

49 G. Sundholm, Acta Chem. Scand., 1971, 25, 3188-3189.

50 X. Wang, Y. Xu, F. Mo, G. Ji, D. Qiu, J. Feng, Y. Ye, S. Zhang, Y. Zhang and J. Wang, J. Am. Chem. Soc., 2013, 135, 1033010333.

51 J.-J. Dai, C. Fang, B. Xiao, J. Yi, J. Xu, Z.-J. Liu, X. Lu, L. Liu and Y. Fu, J. Am. Chem. Soc., 2013, 135, 8436-8439.

52 G. Danoun, B. Bayarmagnai, M. F. Grünberg and L. J. Gooßen, Angew. Chem., Int. Ed., 2013, 52, 7972-7975. 